\title{
Article \\ Effect of Soil Moisture Regimes on the Glyphosate Sensitivity and Morpho-Physiological Traits of Windmill Grass (Chloris truncata R.Br.), Common Sowthistle (Sonchus oleraceus L.), and Flaxleaf Fleabane [Conyza bonariensis (L.) Cronq.]
}

\author{
Arslan Masood Peerzada *(D, Alwyn Williams (D), Chris O’Donnell and Steve Adkins (D) \\ School of Agriculture and Food Sciences, The University of Queensland, Gatton, QLD 4343, Australia; \\ alwyn.williams@uq.edu.au (A.W.); c.odonnell@uq.edu.au (C.O.); s.adkins@uq.edu.au (S.A.) \\ * Correspondence: a.peerzada@uq.edu.au
}

check for updates

Citation: Peerzada, A.M.; Williams, A.; O'Donnell, C.; Adkins, S. Effect of Soil Moisture Regimes on the Glyphosate Sensitivity and Morpho-Physiological Traits of Windmill Grass (Chloris truncata R.Br.), Common Sowthistle (Sonchus oleraceus L.), and Flaxleaf Fleabane [Conyza bonariensis (L.) Cronq.]. Plants 2021, 10, 2345. https://doi.org/ 10.3390/plants10112345

Academic Editors: Amar Matloob, Giuseppe Fenu and Muthukumar Bagavathiannan

Received: 20 August 2021

Accepted: 28 October 2021

Published: 29 October 2021

Publisher's Note: MDPI stays neutral with regard to jurisdictional claims in published maps and institutional affiliations.

Copyright: (c) 2021 by the authors. Licensee MDPI, Basel, Switzerland. This article is an open access article distributed under the terms and conditions of the Creative Commons Attribution (CC BY) license (https:/ / creativecommons.org/licenses/by/ $4.0 /)$.

\begin{abstract}
The glasshouse study was conducted with the objectives of (i) investigating the effect of soil moisture variations on the control efficiency of glyphosate on windmill grass (Chloris truncata R.Br.), common sowthistle (Sonchus oleraceus L.), and flaxleaf fleabane [Conyza bonariensis (L.) Cronq.], (ii) evaluating the tolerance of tested weed species under soil moisture variations, and (iii) determining the morphological and physiological characteristics of these species to partially explain herbicide tolerance under periods of reduced soil moisture availability (RSM). The species' tolerance to glyphosate increased significantly under reduced soil moisture availability $(p<0.001)$. The lethal dose to cause herbicide injury or biomass reduction by $50 \%\left(\mathrm{LD}_{50}\right)$ and $80 \%\left(\mathrm{LD}_{80}\right)$ in relation to untreated control for water-stressed plants [i.e., moderate soil moisture availability (MSM) and RSM] was significantly higher than that of plants grown under high soil moisture availability (HSM). The tolerance factor (TF) for C. truncata, S. oleraceus, and C. bonariensis, in terms of biomass reduction under RSM, was 2.6, 2.4, and 2.6, respectively, as compared to HSM. The results showed that the glyphosate sensitivity, especially at the sub-lethal rates, of the three weed species under study decreased as soil moisture availability reduced $(p<0.01)$. Overall glyphosate efficacy, in relation to the recommended rate, was unaffected, except for $C$. truncata; the weed survived the highest tested glyphosate rate [750 $\mathrm{g}$ active ingredient (a.i.) ha ${ }^{-1}$ ] under RSM. There was significant interaction between weed species and soil moisture regimes for weed morpho-physiological traits $(p<0.001)$, with reduced soil moisture having a more influential impact on the growth of $C$. bonariensis and S. oleraceus compared to C. truncata. Changes in the leaf characteristics, such as increased leaf thickness, higher leaf chlorophyll content, reduced leaf area, and limited stomatal activity for all the tested weed species under MSM and RSM in relation to HSM, partially explain the tolerance of species to glyphosate at sublethal rates.
\end{abstract}

Keywords: climate-induced herbicide tolerance; northern grain region; herbicide sensitivity; summer fallow; climatic stress

\section{Introduction}

Windmill grass (Chloris truncata R.Br.), common sowthistle (Sonchus oleraceus L.), and flaxleaf fleabane [Conyza bonariensis (L.) Cronq.] are the most important weed species of Australia's northern grain region (NGR), mainly due to their prolific production of highly dispersive seeds, low innate seed dormancy, prolonged emergence period, rapid plant maturity, and high risk of evolving glyphosate resistance [1]. These ephemeral, summergrowing weed species germinate following episodic summer rain and grow on summer fallows, transpiring water that could otherwise be stored in the soil for use by subsequent cash crops [2]. Additionally, the primary source of nitrogen (N) for subsequent cash crops comes from the mineralization of organic matter following summer rainfall events [3]. 
Thus, weed infestations during the summer fallows reduce mineral $\mathrm{N}$ availability, either by drying the soil or by accumulating $\mathrm{N}$ in weed biomass, which negatively impacts subsequent crops by reducing grain yield and protein content. Therefore, the management of summer fallow weeds is critical since the cost of controlling such weeds will be much lower than if they are left unmanaged [4].

Glyphosate (N-[phosphonomethyl]-glycine) has become the most widely used nonselective herbicide since its commercialisation by Monsanto in the 1970s [5]. Being a systemic herbicide, it disrupts the synthesis of aromatic acids via the shikimic acid pathway by competitive inhibition of the chloroplast localised enzymes, EPSP (5-enol pyruvylshikimate-3-phosphate) synthase [6]. Due to its desirable characteristics, such as high efficacy, broad spectrum, low cost, and a good toxicological profile, combined with the introduction of genetically modified herbicide-tolerant crops, glyphosate is widely considered to be the most important herbicide for summer fallow weed management $[4,7]$. However, glyphosate has been used with variable levels of success in the northern grain region (NGR) of Australia [8-12].

Practical experience shows that glyphosate's success as a broad-based herbicide, resting on the promise of ever-increasing farm efficiency and productivity, relies not only on its chemical properties but also on its interaction with the plant and the environment $[8,11]$. Besides plant morpho-physiologic, anatomic, and molecular characteristics, environmental conditions before, during, or after herbicide application play a pivotal role in determining the efficacy and performance of glyphosate [13]. In the regions where summer temperatures are projected to increase, rainfall deficiencies resulting from high variability often result in water-deficit stresses, which severely influence plant growth, development, and survival depending on the severity and duration of stress, plant species, and the stage of growth at which stress occurs [14-16].

Changes in soil water potential affect weed growth and development and may also affect herbicide efficacy $[17,18]$. Numerous greenhouse and growth chamber studies have demonstrated that reduced soil moisture reduces the effectiveness of glyphosate on barnyard grass (Echinochloa crus-galli (L.) Beauv.], common milkweed (Asclepias syriaca L.), Johnsongrass [Sorghum halepense (L.) Pers.], purple nutsedge (Cyperus rotundus L.), wild oat (Avena fatua L.), liverseed grass (Urochloa panicoides Beauv.), and awnless barnyard grass [Echinochloa colona (L.) Link] [11,12,19-23]. The possible mechanism associated with the reduced activity of glyphosate is related to alterations in herbicide retention, absorption, translocation, and/or metabolism due to changes in leaf thickness, leaf area, and stomatal conductance $[20,22,23]$. These morphological and physiological changes in the leaf architecture and surfaces, which alter herbicide absorption, translocation, and metabolism, reduce the efficacy of glyphosate under moisture-deficit stress.

Regional projections suggest that south-eastern Australia will be drastically affected by changes in rainfall patterns, as well as rising temperatures, which increase the severity of the drought [24]. The highest level of genetic diversity and the ability to withstand drought will allow some weeds to escape chemical management successfully or partially and, thus, adapt, establish, and spread across the agroecosystems $[25,26]$. Though soil moisture directly influences weed physiology, some species have a higher tolerance than other species [27], depending on the relationship between selection pressure and gene-flow. Therefore, the differences in response to water stress due to their alternation in various phenological and physiological processes, which vary with the degree and length of water stress [28], could influence herbicide tolerance, either positively or negatively.

Based on the above-mentioned literature, it was hypothesized that glyphosate efficacy would decrease under drought conditions as weed tolerance to herbicide would increase under severe moisture-deficit stress [29,30], but the impact would be speciesand rate-specific. The objectives of the present study were (i) to quantify the growth and physiological responses of three problematic weed species (C. truncata, S. oleraceus, and C. bonariensis) of NGR of Australia when grown under different soil moisture regimes, (ii) examine the effect of different soil moisture regimes on the efficacy of glyphosate when 
applied to these three problematic weed species, and (iii) to determine which growth and physiological responses may be responsible for the water stress-induced tolerance to glyphosate.

\section{Results}

\subsection{Impact of Soil Moisture Variations on Weed Susceptibility to Glyphosate}

Glyphosate application resulted in a significant reduction in the leaf chlorophyll content of $C$. truncata, S. oleraceus, and C. bonariensis $(p<0.001$; Figure 1$)$ when compared to non-treated controls under high (HSM) and moderate soil moisture availability (MSM). However, a gradual increase in leaf chlorophyll content was observed for all the tested weeds at 4 DAA when glyphosate was applied at sublethal rates (i.e., 62.5 to $250 \mathrm{~g}$ a.i. ha ${ }^{-1}$ ) under reduced soil moisture availability (RSM), as shown in Figure 1. In the case of C. truncata, the reduction of leaf chlorophyll content, over time (0 to 6 DAA) under HSM ( 81 to $95 \%$ ) and MSM (43 to $75 \%$ ) was higher as compared to RSM (25 to $38 \%$ ) when sprayed above 375 g a.i. ha $^{-1}(p<0.001$; Figure 1).

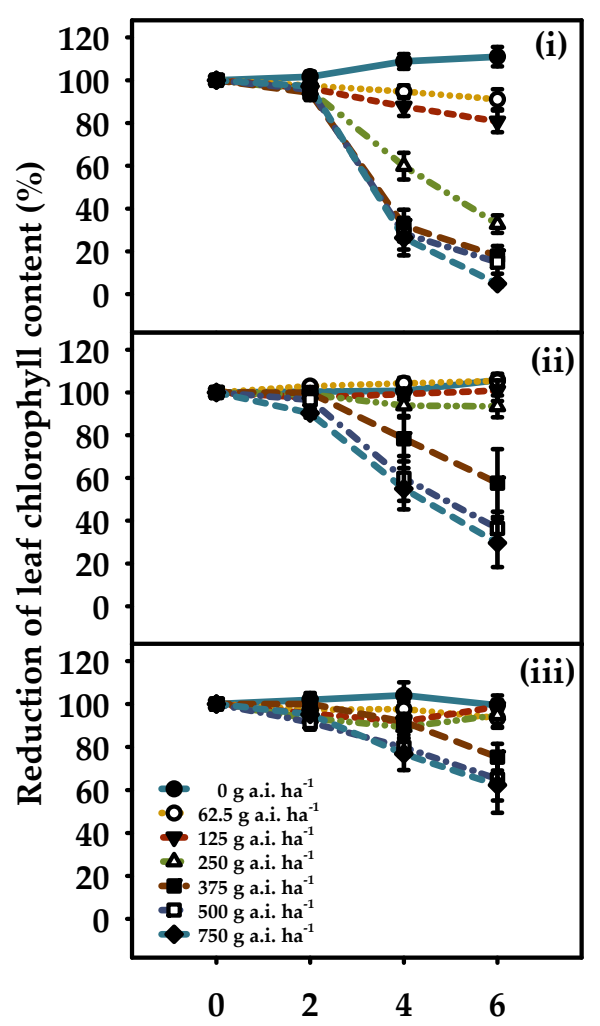

(a)

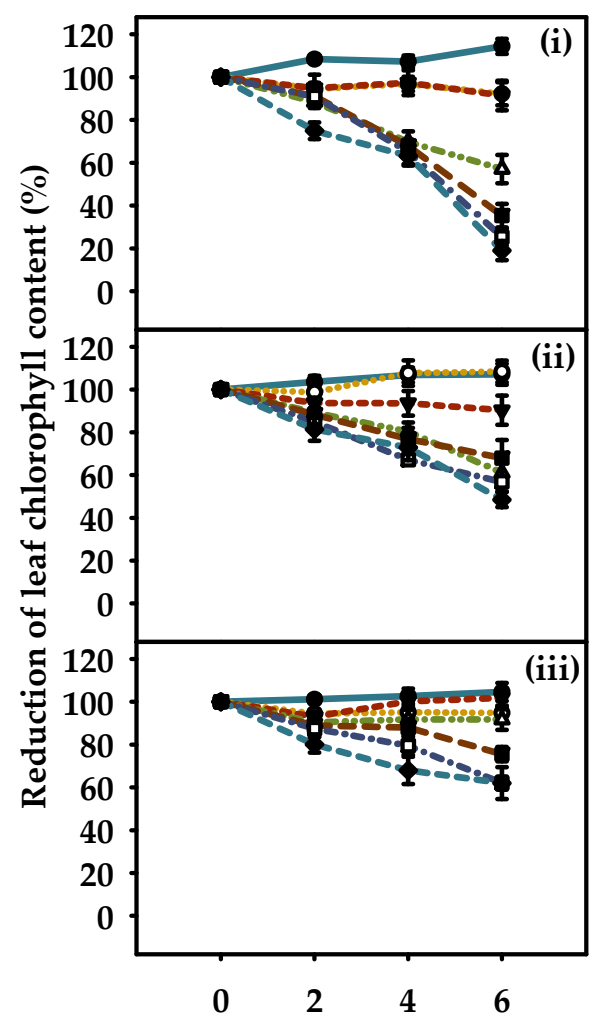

Days after herbicide application (DAA)

(b)

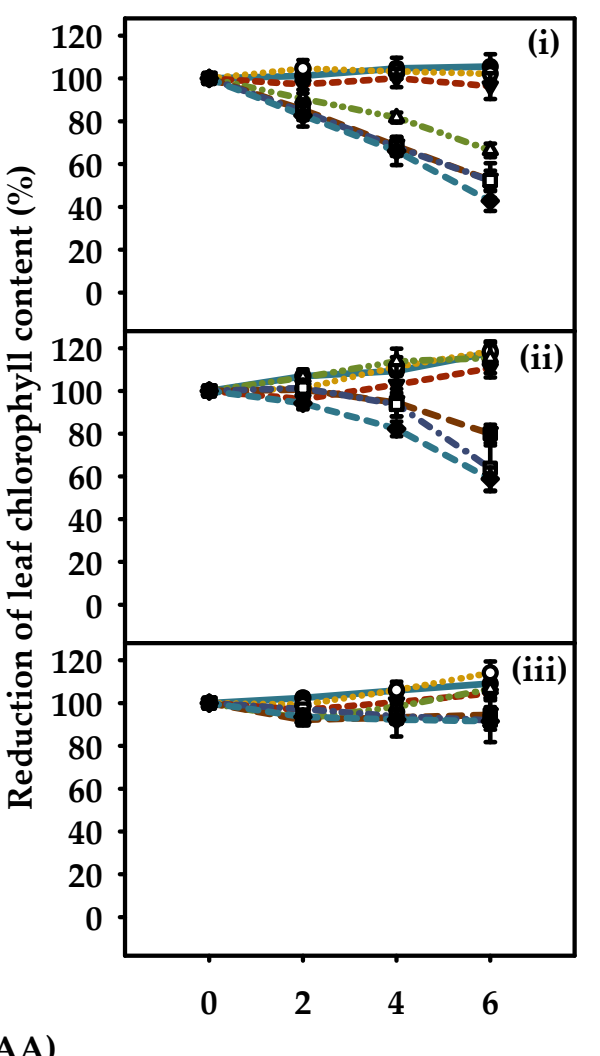

(c)

Figure 1. Reduction of leaf chlorophyll content, estimated in SPAD units, of glyphosate-treated C. truncata (a), S. oleraceus (b), and C. bonariensis (c) plants grown under (i) high soil moisture availability-HSM (90-100\% of the WHC), (ii) moderate soil moisture availability-MSM (50-60\% of the WHC) and (iii) reduced soil moisture availability-RSM (20-30\% of the WHC), over the six days after the glyphosate application at various rates. Error bars represent the \pm two standard errors of the mean $(\mathrm{n}=8)$ from repeated experiments. The recommended rate for the control of C. truncata, S. oleraceus, and C. bonariensis in the Northern Grain Region's summer fallow is 740, 705, and $658 \mathrm{~g}$ a.i. ha ${ }^{-1}$, respectively.

In comparison to SPAD values at 0 DAA, the leaf chlorophyll content for S. oleraceus under HSM decreased by 66 to $80 \%$ at 6 DAA when glyphosate was applied at $>375$, whereas the values ranged between 31 and $52 \%$ and 24 and $39 \%$ under MSM and RSM, respectively $(p<0.001 ;$ Figure 1). An increased level of tolerance was observed in C. bonariensis; plants treated with glyphosate at a rate between 125 and $375 \mathrm{~g}$ a.i. ha ${ }^{-1}$ showed a reduction of 
leaf chlorophyll content by 2 to $48 \%$, whereas the reduction ranged between -10.5 and $21 \%$ and -4 and $5.6 \%$ in MSM and RSM, respectively, at similar rates, in relation to controls at 0 DAA ( $p<0.001$; Figure 1$)$. The results thus confirm differential herbicide sensitivity of tested weed species under soil moisture variations during the first week.

The visual herbicide injury (\%) and biomass reduction (\%) for tested weed species as a function of glyphosate rates and soil water regime, fitted to sigmoidal regression models in Eqn. 1 and Eqn. 2 ( $p<0.001$; Figure 2; Table 1). The values of the determination coefficient $\left(\mathrm{R}^{2}\right)$ varied from 0.81 to 0.98 , demonstrating the satisfactory adjustment of data to the models (Table 1). For all the tested species, a significant effect $(p<0.05)$ of soil water content and herbicide rates could be observed on glyphosate susceptibility. With the lack of overlap of the confidence interval (CI) of the species under well-watered conditions (HSM) in relation to moderate (MSM) and severe water stress (RSM), it was possible to establish the tolerance factor (TF) for both herbicide injury (\%) and biomass reduction (\%) using Equations (2) and (3).

Table 1. Estimated parameter values [upper limit (a), slope (b), and $L D_{50}$ with $95 \%$ confidence intervals (CI) and the tolerance factor (TF)] from the curve fittings using Equations (1) and (2) for the herbicide injury (\%) and biomass reduction $(\%)$ of C. truncata grown under soil moisture regimes, measured at 21 days after treatment in response to glyphosate application at various rates. Standard error values are in parentheses.

\begin{tabular}{|c|c|c|c|c|c|c|c|c|c|}
\hline \multirow{2}{*}{ 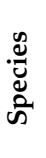 } & \multirow[t]{2}{*}{ Parameters } & \multirow{2}{*}{$\begin{array}{c}\text { Soil Moisture } \\
\text { \% of the } \\
\text { WHC }\end{array}$} & \multirow{2}{*}{$\begin{array}{l}a \\
(\%)\end{array}$} & \multirow[t]{2}{*}{$\mathbf{b}$} & \multicolumn{2}{|c|}{$\mathrm{LD}_{50}$ * } & \multirow[t]{2}{*}{$\mathrm{TF} * *$} & \multirow{2}{*}{$\begin{array}{l}\mathrm{LD}_{80} * * \\
\text { g a.i. ha }{ }^{-1}\end{array}$} & \multirow[t]{2}{*}{$\mathbf{R}^{2}$} \\
\hline & & & & & g a.i. ha-1 & $\begin{array}{c}\text { CI 95\%** } \\
\text { Upper-Lower } \\
\text { Limit }\end{array}$ & & & \\
\hline \multirow{6}{*}{ 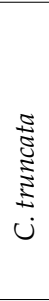 } & \multirow{3}{*}{ Injury (\%) } & $90-100 \%$ & $100.8 \pm 2.5$ & $38.9 \pm 7.0$ & 122.2 & $115.7-128.6$ & 1.0 & 175.2 & 0.91 \\
\hline & & $50-60 \%$ & $101.5 \pm 2.8$ & $68.8 \pm 7.7$ & 244.5 & $235.2-253.7$ & 2.0 & 337.0 & 0.94 \\
\hline & & $20-30 \%$ & $88.2 \pm 4.6$ & $105.8 \pm 14.9$ & 316.7 & $297.0-336.4$ & 2.6 & 528.7 & 0.87 \\
\hline & \multirow{3}{*}{$\begin{array}{c}\text { Biomass } \\
\text { reduction (\%) }\end{array}$} & $90-100 \%$ & $94.6 \pm 8.4$ & $-1.3 \pm 0.5$ & 77.8 & $66.2-89.4$ & 1.0 & 236.1 & 0.81 \\
\hline & & $50-60 \%$ & $93.8 \pm 6.3$ & $-1.9 \pm 0.4$ & 153.9 & $137.5-170.3$ & 2.0 & 338.8 & 0.87 \\
\hline & & $20-30 \%$ & $93.7 \pm 9.1$ & $-1.8 \pm 0.4$ & 239.4 & $208.5-270.3$ & 2.6 & 506.0 & 0.87 \\
\hline \multirow{6}{*}{ 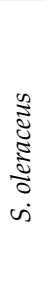 } & \multirow{3}{*}{ Injury (\%) } & $90-100 \%$ & $101.1 \pm 2.8$ & $44.1 \pm 8.1$ & 120.7 & $112.8-128.5$ & 1.0 & 180.4 & 0.88 \\
\hline & & $50-60 \%$ & $103.8 \pm 2.2$ & $73.7 \pm 5.8$ & 225.3 & $218.1-232.6$ & 1.9 & 320.2 & 0.96 \\
\hline & & $20-30 \%$ & $100.9 \pm 2.4$ & $42.7 \pm 5.3$ & 290.4 & $283.7-297.0$ & 2.4 & 348.5 & 0.96 \\
\hline & \multirow{3}{*}{$\begin{array}{c}\text { Biomass } \\
\text { reduction (\%) }\end{array}$} & $90-100 \%$ & $94.7 \pm 5.1$ & $-1.9 \pm 0.4$ & 110.1 & $99.5-120.7$ & 1.0 & 234.6 & 0.85 \\
\hline & & $50-60 \%$ & $102.7 \pm 6.9$ & $-1.8 \pm 0.3$ & 178.9 & 159.4-198.4 & 1.6 & 340.6 & 0.91 \\
\hline & & $20-30 \%$ & $94.1 \pm 2.0$ & $-4.2 \pm 0.4$ & 264.9 & 259.7-270.1 & 2.4 & 373.9 & 0.98 \\
\hline \multirow{6}{*}{ 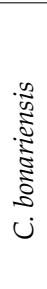 } & \multirow{3}{*}{ Injury (\%) } & $90-100 \%$ & $101.1 \pm 1.1$ & $32.9 \pm 3.2$ & 150.9 & $147.2-154.6$ & 1.0 & 195.6 & 0.98 \\
\hline & & $50-60 \%$ & $102.1 \pm 3.9$ & $61.6 \pm 10.6$ & 250.9 & $239.0-262.7$ & 1.7 & 332.7 & 0.89 \\
\hline & & $20-30 \%$ & $100.6 \pm 2.8$ & $39.9 \pm 5.1$ & 317.6 & $309.8-325.4$ & 2.1 & 372.3 & 0.94 \\
\hline & \multirow{3}{*}{$\begin{array}{c}\text { Biomass } \\
\text { reduction (\%) }\end{array}$} & $90-100 \%$ & $94.9 \pm 1.8$ & $-2.1 \pm 0.1$ & 131.1 & $126.9-135.3$ & 1.0 & 289.0 & 0.98 \\
\hline & & $50-60 \%$ & $96.1 \pm 3.3$ & $-2.7 \pm 0.3$ & 211.6 & 201.9-221.3 & 1.6 & 363.1 & 0.95 \\
\hline & & $20-30 \%$ & $89.3 \pm 3.3$ & $-8.3 \pm 1.6$ & 347.2 & $343.2-361.6$ & 2.6 & 474.2 & 0.92 \\
\hline
\end{tabular}

$\mathrm{LD}_{50}$ is the glyphosate rate $\left(\mathrm{g}\right.$ a.i. ha $\left.{ }^{-1}\right)$ required to cause $50 \%$ injury or biomass reduction; $\mathrm{LD}_{80}$ is the glyphosate rate $\left(\mathrm{g}\right.$ a.i. ha ${ }^{-1}$ ) required to cause $80 \%$ injury or biomass reduction; $\mathrm{R}^{2}$ is the conservative coefficient of determination; $\mathrm{CI} 95 \%=95 \%$ confidence interval; $\mathrm{TF}=$ Tolerance factor; $90-100 \%$ of the WHC = high soil moisture availability (HSM); 50-60\% of the WHC = moderate soil moisture availability (MSM); $20-30 \%$ of the WHC = reduced soil moisture availability (RSM). * Values adjusted by Sigmaplot program. ${ }^{*}$ Estimated index through the Excel spreadsheet. 


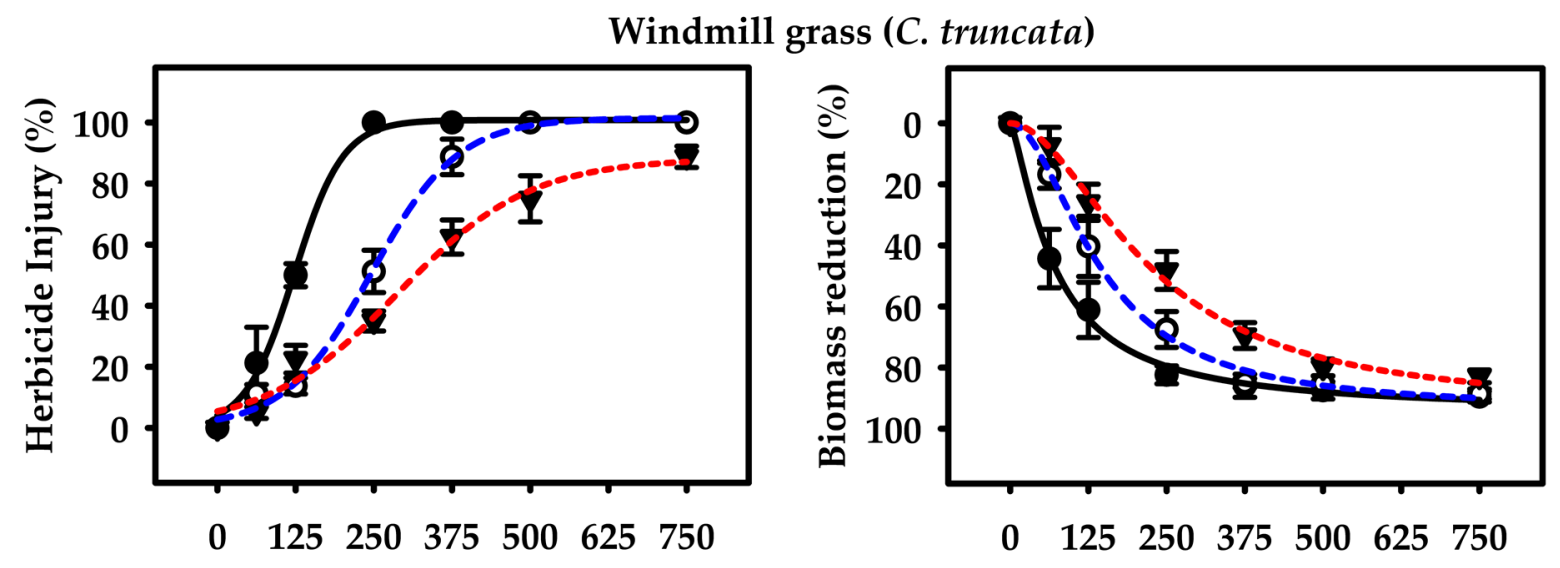

Common sowthistle (S. oleraceus)
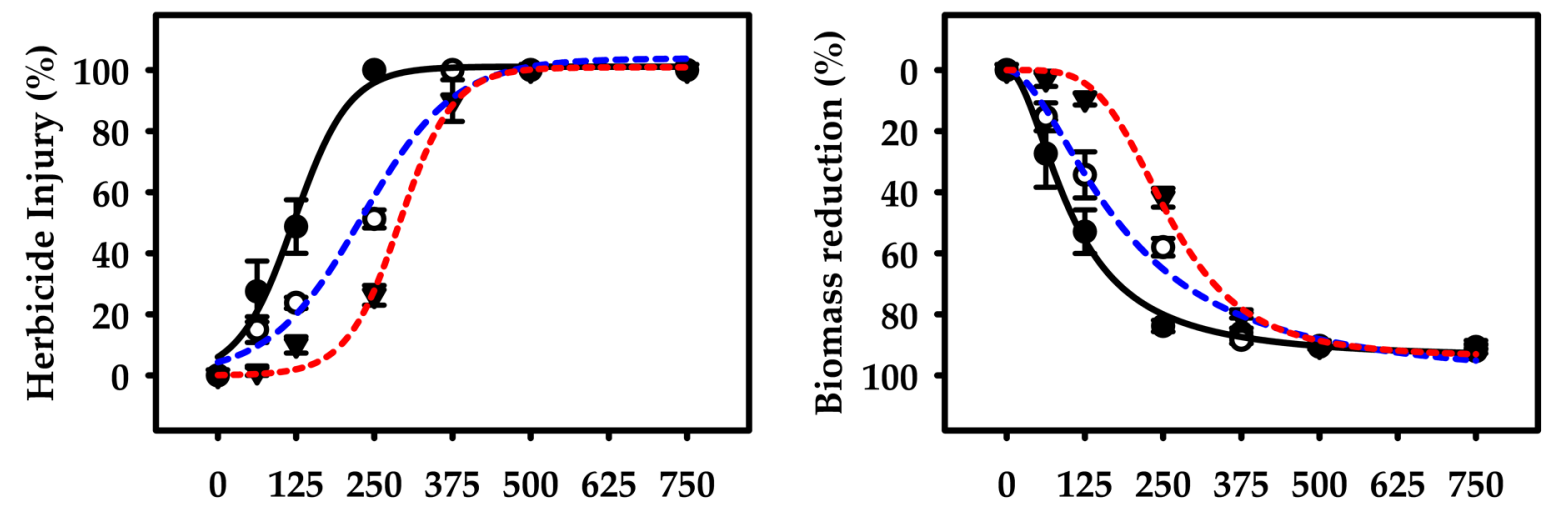

Flaxleaf fleabane (C. bonariensis)

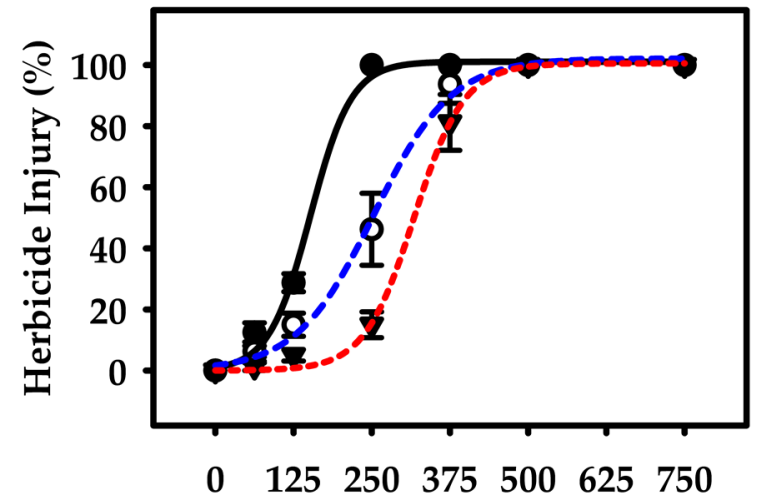

Glyphosate rate (g a.i. $\mathrm{ha}^{-1}$ )

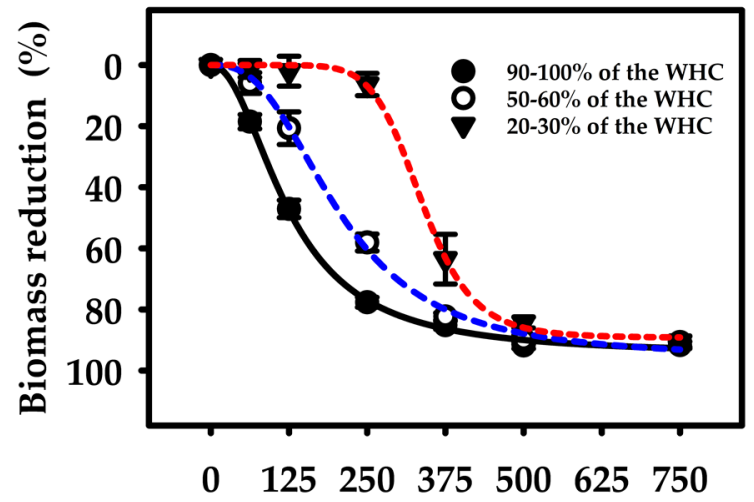

Glyphosate rate (g a.i. $\left.\mathrm{ha}^{-1}\right)$

(a)

(b)

Figure 2. Herbicide control (a) and dry biomass reduction (b) of C. truncata, S. oleraceus, and C. bonariensis as a function of glyphosate rates $\left(0,63,125,250,375,500\right.$, and $750 \mathrm{~g}$ a.i. $\left.\mathrm{ha}^{-1}\right)$ and soil moisture regimes $[(-\mathbf{-}) 90-100 \%$ of the WHC $=$ high soil moisture availability (HSM), (- $(-)$ 50-60\% of the WHC = moderate soil moisture availability (MSM), and ( $\mathbf{\nabla}$ ) 20-30\% of the WHC = reduced soil moisture availability (RSM)] at 21 days after spraying. The figures show the observed data fitted to Equations (1) and (2). Error bars represent the \pm two standard errors of the mean $(n=8)$ from repeated experiments.

The results showed that higher $\mathrm{LD}_{50}$ values $\left(316.7 \mathrm{~g}\right.$ a.i. ha ${ }^{-1}$ ) of glyphosate was required to cause $50 \%$ injury to $C$. truncata under RSM in comparison to other soil water contents; glyphosate at 122.2 and $244.5 \mathrm{~g}$ a.i. $\mathrm{ha}^{-1}$ caused $50 \%$ injury under HSM and MSM, respectively (Figure 2; Table 1). For dry biomass reduction, a similar pattern was observed where a $50 \%$ reduction was recorded with glyphosate at $239.4 \mathrm{~g}$ a.i. ha ${ }^{-1}$ at RSM, which 
is 2 to 2.6 times higher than other soil moisture contents. Thus, the results indicate that C. truncata was 2 to 3-fold more tolerant under MSM and RSM as compared to HSM. The regeneration of lateral shoots was also observed, particularly under MSM and RSM.

Similarly, the $\mathrm{LD}_{50}$ values estimated for the herbicide injury and biomass reduction for $S$. oleraceus and $C$. bonariensis deviated significantly between the soil moisture variations. Glyphosate at $120.7,225.3$, and $290.4 \mathrm{~g}$ a.i. ha $^{-1}$ caused $50 \%$ injury to S. oleraceus under HSM, MSM, and RSM, respectively (Figure 2; Table 1). The $\mathrm{LD}_{50}$ value for biomass reduction under HSM was $110.1 \mathrm{~g}$ a.i. $\mathrm{ha}^{-1}$, whereas the value under MSM and RSM was 178.9 and $264.9 \mathrm{~g}$ a.i. $\mathrm{ha}^{-1}$, respectively. The tolerance factor, based on biomass reduction, at RSM and MSM was 2.4 and 1.6 in comparison to HSM (Table 1). For C. bonariensis, it was determined that 250.9 and $317.6 \mathrm{~g}$ a.i. ha ${ }^{-1}$ were required to cause $50 \%$ injury under MSM and RSM, respectively, and for HSM, it was $150.9 \mathrm{~g}_{\text {a.i. }} \mathrm{ha}^{-1}$ (Figure 2; Table 1). In terms of biomass reduction, plants showed the highest tolerance to glyphosate in RSM, with an LD $_{50}$ of $347.2 \mathrm{~g}$ a.i. ha ${ }^{-1}$, followed by MSM and HSM, with LD $_{50}$ of 211.6 and $131.1 \mathrm{~g}$ a.i. ha ${ }^{-1}$, respectively. The TF values were 1.6 and 2.6 at MSM and RSM, respectively, showing that the rate required to cause $50 \%$ biomass reduction was two times greater than the one required under HSM (Table 1 ).

Although differences in the glyphosate rate to cause $80 \%$ injury or biomass reduction were observed for all tested weed species under soil water variations, results showed that glyphosate within the recommended rates provided satisfactory control of tested weed species (Table 1). For example, glyphosate rates to cause $80 \%$ reduction of dry biomass in C. truncata, S. oleraceus, and C. bonariensis under HSM were 236.1, 234.6, and $289.0 \mathrm{~g}$ a.i. $\mathrm{ha}^{-1}$, respectively. However, the $\mathrm{LD}_{80}$ values under RSM were 506, 340.6, and $474.2 \mathrm{~g}$ a.i. $\mathrm{ha}^{-1}$, which is within the range of glyphosate rates recommended for C. truncata (740 $\mathrm{g}$ a.i. ha $\left.{ }^{-1}\right)$, S. oleraceus (705 g a.i. ha $\left.{ }^{-1}\right)$, and C. bonariensis (658 $\left.\mathrm{g}_{\text {a.i. }} \mathrm{ha}^{-1}\right)$ in the NGR, respectively. Even with such low levels of tolerance, there are indications that there will be increased chances of tolerance to glyphosate under MSM and RSM, especially at the sublethal herbicide rates, which might vary with natural tolerance of the weed species.

\subsection{Impact of Soil Moisture Variations on Weed Morpho-Physiology and Growth}

For all the tested weed species, the plant height attained, the number of leaves produced, their total leaf area, and above-ground plant dry biomass all decreased when exposed to the degree of water stress $(p<0.001$; Tables 2-4). For C. truncata, the plant height at MSM and RSM decreased by $26 \%$ and $46 \%$, respectively, as compared to HSM. The number of leaves produced decreased by $24 \%$ at MSM and 50\% at RSM as compared to HSM. The leaf area was significantly higher for HSM $\left(267.1 \mathrm{~cm}^{2}\right)$, followed by MSM $\left(174.2 \mathrm{~cm}^{2}\right)$ and RSM $\left(129.7 \mathrm{~cm}^{2}\right)$. Compared with HSM, the dry biomass of plants was reduced by $33 \%$ and 58\% at MSM and RSM, respectively. However, the leaf chlorophyll content and leaf thickness all increased when exposed to soil moisture stress conditions (Table 2). The chlorophyll content at MSM and RSM increased by $28 \%$ and $64 \%$, respectively, as compared to HSM. Leaf thickness at MSM and RSM increased by 10\% and 20\%, respectively, as compared to HSM. Stomatal conductance at MSM and RSM decreased by $22 \%$ and $51 \%$, respectively, as compared to HSM.

The response of $S$. oleraceus was similar: water-stress treatments negatively affected nearly all parameters measured at 55-60 days after emergence $(p<0.001$; Table 3$)$. Plant height decreased by $23 \%$ at MSM and $68 \%$ at RSM as compared to HSM. The number of leaves produced at MSM and RSM decreased by 35 and 47\%, respectively, at MSM and RSM as compared to HSM. The chlorophyll content of $S$. oleraceus leaves was significantly higher at MSM (17\%) and RSM (31.1\%) as compared to HSM. However, stomatal conductance decreased as stress intensified; the value decreased by approximately $27 \%$ and $63 \%$ as WHC decreased from HSM to MSM and RSM, respectively. The total leaf area, dependent on plant growth and the number of leaves, was recorded at the highest with HSM, whereas the value decreased by $42 \%$ and $61 \%$ with increasing water stress. Relative to the HSM, the thickness of the leaf at the laminar portion increased substantially by $6 \%$ and $20 \%$ with 
MSM and RSM, respectively. The highest dry biomass was recorded in plants growing at HSM (3.1 g), whereas it was reduced by 32 and $61 \%$ when maintained at MSM and RSM, respectively.

Table 2. Influence of soil moisture regimes on the morpho-physiology and growth of C. truncata, measured at 55 to 60 days after emergence. Data collected from repeated experiments with a total of eight replications per treatment.

\begin{tabular}{|c|c|c|c|c|c|c|c|}
\hline Soil Moisture & $\begin{array}{c}\text { Plant } \\
\text { Height }\end{array}$ & $\begin{array}{l}\text { No. of } \\
\text { Leaves }\end{array}$ & $\begin{array}{c}\text { Chlorophyll } \\
\text { Content }\end{array}$ & $\begin{array}{c}\text { Stomatal } \\
\text { Conductance }\end{array}$ & $\begin{array}{c}\text { Leaf } \\
\text { Thickness }\end{array}$ & Leaf Area & $\begin{array}{c}\text { Dry } \\
\text { Weight }\end{array}$ \\
\hline$\%$ of the WHC & $\mathrm{cm}$ & - & SPAD Units & $\mathrm{mmol} \mathrm{m}^{-2-2} \mathrm{~s}^{-1}$ & $\mu \mathrm{m}$ & $\mathrm{cm}^{2}$ & $\mathrm{~g}$ \\
\hline $90-100 \%$ & $47.8 \pm 2.5$ & $94 \pm 3.4$ & $28.2 \pm 0.4$ & $163.8 \pm 5.2$ & $95.8 \pm 2.1$ & $267.1 \pm 6.1$ & $3.3 \pm 0.1$ \\
\hline $50-60 \%$ & $35.3 \pm 1.3$ & $71 \pm 3.0$ & $36.2 \pm 0.5$ & $127.4 \pm 4.8$ & $105.8 \pm 1.9$ & $174.2 \pm 4.5$ & $2.2 \pm 0.1$ \\
\hline $20-30 \%$ & $25.8 \pm 1.7$ & $47 \pm 2.6$ & $46.2 \pm 0.5$ & $80.6 \pm 2.4$ & $114.6 \pm 1.2$ & $129.7 \pm 3.6$ & $1.4 \pm 0.05$ \\
\hline$p$-value & $<0.001$ & $<0.001$ & $<0.001$ & $<0.001$ & $<0.001$ & $<0.001$ & $<0.001$ \\
\hline $\begin{array}{c}\text { LSD } \\
(p<0.05)\end{array}$ & 5.7 & 8.8 & 1.3 & 12.6 & 5.3 & 14.2 & 0.3 \\
\hline
\end{tabular}

$90-100 \%$ of the WHC = high soil moisture availability (HSM); $50-60 \%$ of the WHC = moderate soil moisture availability (MSM); $20-30 \%$ of the WHC = reduced soil moisture availability (RSM); LSD = Least Significant Difference.

Table 3. Influence of soil moisture regimes on the morpho-physiology and growth of S. oleraceus, measured at 55 to 60 days after emergence. Data collected from repeated experiments with a total of eight replications per treatment.

\begin{tabular}{ccccccccc}
\hline Soil Moisture & $\begin{array}{c}\text { Plant } \\
\text { Height }\end{array}$ & $\begin{array}{c}\text { No. of } \\
\text { Leaves }\end{array}$ & $\begin{array}{c}\text { Chlorophyll } \\
\text { Content }\end{array}$ & $\begin{array}{c}\text { Stomatal } \\
\text { Conductance }\end{array}$ & $\begin{array}{c}\text { Leaf } \\
\text { Thickness }\end{array}$ & $\begin{array}{c}\text { Leaf Area } \\
\text { Weight }\end{array}$ \\
\hline$\%$ of the WHC & $\mathrm{cm}$ & - & SPAD Units & $\mathrm{mmol} \mathrm{m}^{-2} \mathrm{~s}^{-1}$ & $\mu \mathrm{m}$ & $\mathrm{cm}^{2}$ & $\mathrm{~g}$ \\
\hline $90-100 \%$ & $64.8 \pm 1.9$ & $27.6 \pm 1.0$ & $36.0 \pm 1.1$ & $288.9 \pm 6.1$ & $308.5 \pm 5.1$ & $423.5 \pm 15.5$ & $3.1 \pm 0.06$ \\
\hline $50-60 \%$ & $49.6 \pm 1.4$ & $18.0 \pm 0.9$ & $42.1 \pm 1.3$ & $211.5 \pm 4.4$ & $327.4 \pm 6.0$ & $245.5 \pm 14.0$ & $2.1 \pm 0.09$ \\
\hline $20-30 \%$ & $20.5 \pm 0.8$ & $14.5 \pm 1.1$ & $47.2 \pm 1.1$ & $108.2 \pm 5.1$ & $371.2 \pm 9.3$ & $166.2 \pm 8.7$ & $1.2 \pm 0.03$ \\
\hline$p$-value & $<0.001$ & $<0.001$ & $<0.001$ & $<0.001$ & $<0.001$ & $<0.001$ & $<0.001$ \\
\hline $\begin{array}{c}\text { LSD } \\
(p<0.05)\end{array}$ & 4.3 & 2.9 & 3.4 & 15.5 & 20.72 & 38.4 & 0.2 \\
\hline
\end{tabular}

$90-100 \%$ of the WHC = high soil moisture availability (HSM); $50-60 \%$ of the WHC = moderate soil moisture availability (MSM); $20-30 \%$ of the WHC = reduced soil moisture availability (RSM); LSD = Least Significant Difference.

The morpho-physiological and growth responses of $C$. bonariensis were more severely impacted by water stress as compared to $C$. truncata and S. oleraceus $(p<0.001$; Table 4$)$. Plant height decreased by $58 \%$ and $68 \%$ with MSM and RSM, respectively, as compared to HSM. The number of leaves produced at MSM and RSM decreased by 43 to $73 \%$ relative to HSM. The ANOVA showed that the amount of leaf chlorophyll content increased by $14.2 \%$ and $29.1 \%$ under MSM and RSM as compared to HSM. A better water supply (HSM) resulted in significantly higher stomatal conductance, while MSW to RSM reduced stomatal conductance by $47.6-73.3 \%$. Plants subjected to MSM and RSM showed an increased leaf thickness of $14.5 \%$ and $26.5 \%$, respectively, which differed significantly from HSM. The total leaf area reached its maximum at HSM $\left(250.0 \mathrm{~cm}^{2}\right)$, whereas the value reduced as the degree of water stress increased (i.e., $160.9 \mathrm{~cm}^{2}$ at MSM and $87.7 \mathrm{~cm}^{2}$ at RSM). Plant dry weight decreased in both MSM and RSM by $25 \%$ and $67.9 \%$, respectively, as compared to HSM. 
Table 4. Influence of soil moisture regimes on the morpho-physiology and growth of C. bonariensis, measured at 55 to 60 days after emergence. Data collected from repeated experiments with a total of eight replications per treatment.

\begin{tabular}{cccccccc}
\hline Soil Moisture & $\begin{array}{c}\text { Plant } \\
\text { Height }\end{array}$ & $\begin{array}{c}\text { No. of } \\
\text { Leaves }\end{array}$ & $\begin{array}{c}\text { Chlorophyll } \\
\text { Content }\end{array}$ & $\begin{array}{c}\text { Stomatal } \\
\text { Conductance }\end{array}$ & $\begin{array}{c}\text { Leaf } \\
\text { Thickness }\end{array}$ & $\begin{array}{c}\text { Leaf Area } \\
\text { Weight }\end{array}$ \\
\hline$\%$ of the WHC & $\mathrm{cm}$ & - & SPAD Units & $\mathrm{mmol} \mathrm{m}^{-2} \mathrm{~s}^{-1}$ & $\mu \mathrm{m}$ & $\mathrm{cm}^{2}$ & $\mathrm{~g}$ \\
\hline $90-100 \%$ & $39.3 \pm 1.2$ & $97.8 \pm 2.5$ & $35.6 \pm 2.0$ & $360.5 \pm 11.4$ & $293.0 \pm 8.3$ & $250.2 \pm 4.1$ & $2.8 \pm 0.06$ \\
\hline $50-60 \%$ & $16.5 \pm 0.9$ & $55.6 \pm 2.3$ & $41.5 \pm 1.4$ & $188.8 \pm 9.0$ & $335.4 \pm 9.2$ & $160.9 \pm 3.9$ & $2.1 \pm 0.05$ \\
\hline $20-30 \%$ & $12.6 \pm 0.2$ & $25.9 \pm 0.5$ & $50.2 \pm 1.5$ & $96.2 \pm 6.8$ & $367.7 \pm 7.8$ & $87.7 \pm 2.9$ & $0.9 \pm 0.02$ \\
\hline$p$-value & $<0.001$ & $<0.001$ & $<0.001$ & $<0.001$ & $<0.001$ & $<0.001$ & $<0.001$ \\
\hline $\begin{array}{c}\text { LSD } \\
(p<0.05)\end{array}$ & 3.4 & 5.8 & 4.9 & 27.3 & 24.8 & 10.9 & 0.2 \\
\hline
\end{tabular}

$90-100 \%$ of the WHC = high soil moisture availability (HSM); $50-60 \%$ of the WHC = moderate soil moisture availability (MSM); $20-30 \%$ of the WHC = reduced soil moisture availability (RSM); LSD = Least Significant Difference.

\section{Discussion}

\subsection{Impact of Soil Moisture Variations on Weed Susceptibility to Glyphosate}

Several studies have highlighted the influence of limited moisture availability on the glyphosate sensitivity of weed species, but the information available on the response of C. truncata, S. oleraceus, and C. bonariensis is scarce. Glyphosate efficacy decreased as soil moisture decreased, as evidenced by leaf chlorophyll reduction (\%), herbicide injury (\%) and biomass reduction (\%) for all three weed species. These results support that soil moisture content plays a critical role in predicting the efficacy of glyphosate on these weed species, particularly on $C$. truncata and C. bonariensis. These results also support the assertion that the difference in $\mathrm{LD}_{50}$ and $\mathrm{LD}_{90}$ values between stressed and non-stressed plants is due to a difference in the plant-herbicide-moisture interactions.

Studies have reported SPAD readings as a good predictor of leaf chlorophyll content [31]; few studies have used this method in assessing glyphosate activity [32]. Analysis of variance related to the main effect of glyphosate and weed species indicated significant differences in leaf chlorophyll content across soil moisture regimes. The leaf chlorophyll in C. truncata, S. oleraceus, and C. bonariensis content declined significantly following application of glyphosate under HSM (Figure 1). However, moderate to a minimum reduction in leaf chlorophyll content values were recorded under MSM and RSM, respectively. Our findings were at par with the findings of Tanpipat [32]. The results indicated that glyphosate within recommended rates under HSM and MSM was effective and consistent in causing a significant reduction in leaf chlorophyll content, while all the tested weed species showed increased tolerance when grown under RSM, with C. bonariensis showing the highest values. The increased herbicide tolerance under RSM could possibly be due to the presence of trichomes which restrict or delay the penetration and absorption of glyphosate [33].

Despite slight to moderate differences at sub-lethal rates, glyphosate application at the recommended rate under HSM caused the highest herbicide injury and resulted in the lowest weed growth as indicated by poor dry biomass accumulation for all the three tested weed species (Table 1; Figures 1 and 2). However, under RSM, this response to glyphosate was species-specific, as C. truncata tolerated glyphosate more efficiently than S. oleraceus and C. bonariensis, resulting in 10\% more plant survival and more biomass at the highest tested rate. Plants of $C$. truncata at sub-lethal rates lost apical dominance and initiated multiple lateral buds when grown under MSM and RSM. In addition, glyphosate at 62.5 and $125 \mathrm{~g}$ a.i. ha ${ }^{-1}$ stimulated seedling growth under MSM and RSM, possibly due to its hormetic effect [34].

Taken across all three soil water conditions, herbicide activity shows a correlation with the soil moisture regime, as has been demonstrated for several post-emergent herbicides $[13,35]$. Though species' tolerance to glyphosate increased two to three-folds under the water-stressed conditions relative to the well-watered condition, glyphosate appli- 
cation within the recommended rates provided complete control of all the tested weed species. These results were in line with the finding of Adkins et al. [11], Adkins et al. [12] and Tanpipat [32] on U. panicoides, E. colona, and A. fatua that a reduced soil moisture content resulted in increased species' tolerance and the time required to control the same population under optimal water conditions. Similar observations for glyphosate were also reported in other species, such as black nightshade (Solanum nigrum L.), cogon grass [Imperata cylindrical (L.) Beau.], and purple nutsedge [Cyperus rotundus (L.) Pers.] [22,36].

Though the study indicated that the tested weed species differ in their sensitivity to glyphosate rates under varying soil moisture conditions, the fundamental reasons behind the increased herbicide tolerance at RSM reduced soil water content are not known; studies on herbicide absorption, translocation, and metabolism under water-deficit stress could explain the phenomenon behind increased tolerance. With respect to glyphosate, nothing has been reported previously to explain its reduced activity in C. truncata, S. oleraceus, and C. bonariensis when applied under moisture stress. One further possibility of increased water stress-induced tolerance in the present study could be that the generated water stress altered the morpho-physiology, and this may lead to reduced glyphosate interception, penetration, absorption, and translocation. These changes in physiological as well as morphological responses to reduced soil moisture conditions or water stress are reported for the relative inefficiency of glyphosate against weeds under extreme soil moisture stress [22]. These morpho-physiological adaptive adjustments in response to reduced soil water content could enable weed species to avoid or escape glyphosate treatment. Possibilities exist that glyphosate at recommended rates might act as sublethal rates, depending upon the species' natural tolerance, when sprayed in periods of drought, which might help weeds in resistant evolution over multiple generations [37].

\subsection{Impact of Soil Moisture Variations on Weed Morpho-Physiology and Growth}

The objective of this study was to quantify the growth response under varying soil moisture regimes in C. truncata, S. oleraceus, and C. bonariensis. For all the tested weed species, highly significant differences in growth parameters were recorded across varying soil moisture regimes (Tables 2-4). The reduction in the availability of water imposed structural changes on the leaves and affected their physiological performance. Leaf structural and physiological traits varied significantly in response to water regimes in all the species. The present data is similar to that seen previously where water stress has been shown to reduce plant height, leaf area, plant biomass, and root:shoot ratio [38,39]. In addition, other studies have shown water stress to affect many plant processes, such as photosynthesis, protein synthesis, and the build-up of metabolites $[40,41]$. Such changes may explain the substantial decrease in the leaf number and area, and, in turn, in plant biomass seen in our study. The reduction in leaf mass and area could be from producing smaller, thicker leaves and reducing stomatal conductance, as observed in our study, to minimize water loss through epidermal cells [42].

Previous studies have reported a substantial reduction in growth, physiology, and seed production of several weed species, including barnyard grass [Echinochloa crus-galli (L.) Beauv.], velvetleaf (Abutilon theophrasti Medicus), black knapweed (Centaurea nigra L.), and pigweed (Amaranthus retroflexus L.) under varying degrees and durations of water stress [42-45]. A recent study on C. truncata also reported that the productivity of the plants, as measured by the dry biomass per plant, was reduced with moisture stress [46]. These studies reported that water stress affects most growth functions, but these effects depend on the level of water stress, the length of time the plants are subjected to it, and the plant species [47].

Though the herbicide within the recommended rate provided complete control of the tested weed species, increased tolerance to sub-lethal rates could be crucial for understanding the eco-evolutionary insight of climate-induced herbicide tolerance and the slow evolution of herbicide resistance. The morpho-physiological and growth features can partially explain the variations between the species and water-deficit stress against 
herbicides, especially at sublethal rates. For example, plants of C. truncata, S. oleraceus, and C. bonariensis when exposed to water stress showed certain symptoms, such as reduced plant height and leaf surface area, altered leaf position or angle, and stunted growth or reduced biomass production, and leaf folding (i.e., C. truncata). These morphological features related to leaf surface characteristics, especially leaf architecture (e.g., leaf area and angle), as well as height, in relation to the spray nozzle, directly influence the amount of herbicide spray droplet deposition and retention on the leaf surface [47-49]. In addition, water-deficit conditions increase leaf cuticle thickness, as observed in our study, alter the epicuticular wax composition, and increase total wax content [50], which can inhibit the absorption and penetration of post-emergent herbicides, such as glyphosate [51].

With the onset of water-deficit stress, the stomatal conductance of matured and fullydeveloped leaves declined in C. truncata, S. oleraceus, and C. bonariensis to restrict water transpiration, in order to avoid dehydration [52]. Thus, decreased stomatal conductance or the number of stomata reduces the penetration of glyphosate into leaves, which also reduces the efficacy of glyphosate [53]. As the stomatal conductance is reduced, due to decreased xylem water potential, photosynthesis and transport of photosynthates out of the leaf decreases $[54,55]$, which restricts the translocation of phloem-mobile herbicides like glyphosate.

There is also indirect evidence that chlorophyll is jointly controlled by climate and soil. Thus, chlorophyll might be an indicative trait for characterising how plants respond to climate change. Earlier studies have found that photosynthesis is not the primary inhibitory target of glyphosate, and glyphosate injury is found to be correlated with chlorophyll content $[56,57]$. In our study, the content of chlorophyll in the leaves of tested species increased significantly in response to water stress, which is the most interesting trait. Tolerance to glyphosate under MSM and RSM, especially at sublethal rates, could possibly be related to the higher leaf chlorophyll content, which has not been investigated before. This can be justified by the findings of Darwish et al. [58], who reported a differential response of two tobacco varieties to clomazone, which inhibits biosynthesis of photosynthetic pigments, because both chlorophyll and carotenoids were two times higher in Virginie compared to Xanthi. Possibilities exist that a higher leaf chlorophyll content under water stress will increase the number of target-sites (EPSPS), and glyphosate molecules at the recommended rate might act as sublethal, thus requiring further investigation.

\section{Materials and Methods}

\subsection{Seed Collection}

The seeds of windmill grass (Chloris truncata R.Br.), common sowthistle (Sonchus oleraceus L.), and flaxleaf fleabane [Conyza bonariensis (L.) Cronq] were collected during 2017/2018 from southeast and central Queensland (QLD) with locations being recorded by geographic positioning systems (GPS). These species were selected based on previous reports of unsatisfactory control with glyphosate, their invasiveness and impact characteristics, their current and potential area of spread, and their environmental and socioeconomic impacts on Australia's NGR. Three or four biotypes of each species were collected to examine intraspecific variation across a large geographic area. The seeds of each collected biotype were dried in the shade for $~ 7-10$ days, separated from the chaff, mixed thoroughly, and stored under paper bags in a seed storage room $\left(15 \pm 1{ }^{\circ} \mathrm{C} ; 15 \pm 3 \%\right.$ relative humidity) until used.

\subsection{Dose-Response Study to Determine $L D_{50}$ and $L D_{80}$ Values}

A preliminary rate-response study was conducted to identify the glyphosate susceptibility levels for each biotype of the weed species. Based on the results, the highly susceptible biotype for each weed species was used in the water-stress experiment. The $\mathrm{LD}_{50}$ recorded for the highly susceptible biotypes of $C$. truncata, $S$. oleraceus, and C. bonariensis, based on biomass reduction, were 80.0, 79.3, and $130.2 \mathrm{~g}$ a.i. $\mathrm{ha}^{-1}$, respectively, when grown in a glasshouse with a mean temperature of $30 / 20 \pm 2{ }^{\circ} \mathrm{C}$, a photoperiod of $12 / 12 \mathrm{~h}$ (day/night), and relative humidity of $65 \pm 5 \%$ (data not presented). 


\subsection{Determination of Water Holding Capacity}

For both the experiments, seedlings of tested weed species were grown at 3 different soil moisture regimes: $90-100 \%, 50-60 \%$, and $20-30 \%$ of the water holding capacity (WHC), determined by the soil gravimetric method of Gardner [59], modified by Adkins et al. [12] and Tanpipat et al. [8]. The procedure has been discussed in detail by Peerzada [60] and Bajwa et al. [25]. Based on that calculation, $90-100 \%$ of the WHC (high soil moisture availability-HSM), 50-60\% of the WHC (moderate soil moisture availability-MSM), and $20-30 \%$ of the WHC (reduced soil moisture availability-RSM) were determined. For HSM treatment, plants (now 4-5 days old) in the first batch were allowed to dry down to $90 \%$ of the WHC before being watered back to $100 \%$. For MSM treatment, plants in the second batch were allowed to dry down to $50 \%$ of the WHC before being watered back to $60 \%$ and then kept at this level until harvest. For RSM treatment, plants in the third batch were allowed to reach $20 \%$ of the WHC before being watered to $30 \%$ of the WHC and then kept at this level until harvested.

\subsection{Impact of Soil Moisture Variations on Weed Susceptibility to Glyphosate}

The experiments were conducted in the temperature-controlled glasshouse facility at the School of Agriculture and Food Sciences (SAFS), The University of Queensland $(-27.51,152.26)$, Gatton, during the summer of 2018-2019 and repeated in the same year. C. truncata, S. oleraceus, and C. bonariensis seedlings were established in each plastic pot (10$\mathrm{cm}$ diameter) containing ca. $500 \mathrm{~g}$ of sun-dried soil collected from the UQ Crop Research Unit, The University of Queensland. At the 2-leaf stage, pots were allowed to continue growing under 3 soil moisture regimes as described above (HSM, MSM, and RSM). These 4 to 5-day old seedlings were grown and, later, maintained in a glasshouse with a mean temperature of $28 / 20 \pm 2{ }^{\circ} \mathrm{C}$, a photoperiod of $12 / 12 \mathrm{~h}$ (day/night), and a relative humidity of $65 \pm 5 \%$.

The plants of $C$. truncata were treated with glyphosate at the early tillering stage ( 17-21 days after emergence), while S. oleraceus and C. bonariensis were treated at the rosette stage ( 21-24 days after emergence and at the 6 to 8 leaf stage) with one of 7 concentrations of glyphosate $[0,62.5,125,250,375,500$, and $750 \mathrm{~g}$ active ingredient (a.i.) $\mathrm{ha}^{-1}$ ]. The number of days to reach the abovementioned stage in HSM varied from 3 to 10 days for MSM and RSM. The glyphosate applied was WeedMaster DST ${ }^{\circledR}$ salts (Nufarm, Victoria, Australia), and the original concentration of glyphosate $\left(470 \mathrm{~g} \mathrm{~L}^{-1}\right)$ was present as potassium and mono-ammonium. The application was undertaken in an enclosed cabinet track sprayer fitted with a Teejet nozzle (8003E) delivering $100.38 \mathrm{~L} \mathrm{ha}^{-1}$ at $300 \mathrm{kPa}$. The herbicide was sprayed with the lowest rate of glyphosate first and finished with the highest rate. After herbicide application, the pots were transferred back within $30 \mathrm{~min}$ to their respective growing conditions in the temperature-controlled glasshouse.

Glyphosate sensitivity was recorded in 3 ways; viz. by a reduction in leaf chlorophyll content [as assessed by the SPAD meter (SPAD 502, Minolta Konica Ltd., Ramsey, NJ, USA)], by herbicide injury (\%) at 21 days after glyphosate application (DAA), and by shoot dry biomass reduction at 21 DAA. For measuring the reduction in leaf chlorophyll content, SPAD values taken from treated plants and control plants were converted into a percent reduction in SPAD units, as an indication of declining chlorophyll content. In the second method, the injury level was visually assessed for herbicide symptoms, taking into account their visual appearance (e.g., tissue colour and necrosis, and other abnormalities) at 21 DAA using a modified scale proposed by Frans [61]. For measuring the biomass reduction at 21 DAA, the above-ground biomass of each biotype was determined by cutting shoots just above the soil surface, and oven-drying them for $72 \mathrm{~h}$ at $65^{\circ} \mathrm{C}$.

\subsection{Impact of Soil Moisture Variations on Weed Morpho-Physiology and Growth}

The seeds of $C$. truncata, S. oleraceus, and C. bonariensis were planted, and seedlings were raised in plastic pots $(17 \mathrm{~cm}$ in diameter), containing $2.5 \mathrm{~kg}$ of heavy clay loam soil collected from the UQ Gatton campus, to study the effect of reduced soil moisture 
on weed growth. At the 3-leaf stage (ca. 4 to 5 days after seedling emergence), the seedlings were thinned to one uniform seedling per pot. From that point on, twelve pots per species were divided into 3 batches (HSM, MSM, and RSM) and monitored for growth and morphological differences. These 4 to 5-day-old seedlings were grown and, later, maintained in a glasshouse with a mean temperature of $28 / 20 \pm 2{ }^{\circ} \mathrm{C}$, a photoperiod of $12 / 12 \mathrm{~h}$ (day/night), and relative humidity of $65 \pm 5 \%$. The plant growth (viz. height attainment, number of leaves produced, leaf area developed, leaf thickness, chlorophyll content, stomatal conductance, and dry biomass) were all measured ca. 55 to 60 days after emergence (DAE), depending upon the weed species (see Peerzada [60] for details).

\subsection{Experimental Designs and Statistical Analysis}

Data from the 2 repeats of the study were pooled before analysis as the effect of the repeat was non-significant $(p<0.05)$ for most of the parameters measured. For the study on glyphosate efficacy, the experimental design was a 2-factor nested design including 7 glyphosate rates and 3 soil moisture regimes per weed species with 4 replications. The interval data on chlorophyll content was presented in line graphs to show the trend over time. Visual herbicide injury (\%) was regressed over herbicide treatments using the 3-parameter sigmoid-sigmoidal model in Sigmaplot ${ }^{\circledR} 14.5$ (Systat Software, Inc., San Jose, CA, USA).

$$
y=\frac{a}{1+e^{-\left(\frac{x-x_{0}}{b}\right)}}
$$

In this regression model, $b$ is the slope, $a$ is the maximum visually assessed injury, $x$ is the herbicide rate ( $\mathrm{g}$ a.i. ha ${ }^{-1}$ ), and $x_{\mathrm{o}}$ is the rate providing $50 \%$ response of the variable. Dry shoot biomass reduction was regressed over herbicide treatments using the 3-parameter logistic-sigmoidal model;

$$
y=\frac{a}{1+\left(\frac{x}{x_{0}}\right)^{b}}
$$

In this regression model, $a$ is denominated "saturation level", corresponding to the bio-indicator response at the lower rate, $x_{\mathrm{o}}$ is the inflection point of the curve, which corresponds to the $L D_{50}$ value, and $b$ describes the slope of the curve around $L D_{50}$. Based on the analysis of the rate-response curves, the values of $L D_{50}$ (rate required to cause $50 \%$ biomass reduction) with $95 \%$ confidence intervals (CI) and $L D_{80}$ (rate required to cause $80 \%$ biomass reduction) values were estimated using Sigmaplot 14.0 and Microsoft@Excel 2016 (Microsoft Corporation, Redmond, WA, USA). For individual weed species, the difference between qualitative (herbicide injury and biomass reduction) and quantitative variables (herbicide, rate, and soil moisture) were assessed by the CI. Overlapping CIs mean that there is no significant difference, whereas non-overlapping CIs indicate a significant difference. The estimated results of herbicide injury and biomass reduction of the weed species were also subjected to analysis of variance (ANOVA) using a general linear model (GLM) approach implemented in Minitab ${ }^{\circledR}$ (Minitab Inc., State College, PA, USA). To quantify the relative susceptibility of glyphosate under different soil moisture regimes, the ratio of tolerance to susceptibility, referred to as the tolerance factor (TF) index, was calculated (Equation (3)).

$$
T F=\frac{L D_{50}(R S M) \text { or } L D_{50}(M S M)}{L D_{50}(H S M)}
$$

If the TF is not significantly different from 1.0 , the $L D_{50}$ is not different from unity, meaning there is no difference of efficacy in relation to the soil moisture regime.

For growth determination, the overall effect of soil moisture variations on the growth of the weed species was determined by means of a one-factor nested design including 3 soil moisture regimes per weed species with 4 replications, and treatment means were separated using Fisher's protected LSD test at $p<0.05$. 


\section{Conclusion and Future Directions}

Results demonstrated that soil moisture-deficit stress induced more than two-fold glyphosate tolerance in tested weed species in comparison to the maximum soil moisture availability. Glyphosate susceptibility was considerably reduced in the control of tested weed species, especially at sublethal rates. The tolerance of glyphosate to sublethal rates could be related to decreased stomatal conductivity, increased thickness of leaves, high levels of chlorophyll in leaves, and decreased area of leaves. These changes under moderate and severe moisture-deficit stress could have interfered with the interception, retention, absorption, and translocation of glyphosate, but it did not affect the overall efficacy. Given the growing number of mild to severe forms of drought in the NGR, especially in the summer fallows, soil moisture levels at the time of application may interfere and reduce the efficacy of glyphosate when applied at recommended rates, depending upon the natural tolerance of weed biotypes to glyphosate. To avoid the efficacy reduction of glyphosate in the periods of drought, guidelines should be developed to improve weed control via manipulating application techniques, such as spray timing, use of adjuvants, different formulations, tank-mixing with contact herbicides, etc. which require further investigations.

The study also highlights that climatic variables, herbicide rate, and weed species, as well as their natural tolerance, interact to affect glyphosate tolerance. Therefore, understanding these relationships will ultimately provide better predictability of how a specific weed species and their ecotypes with differential natural herbicide tolerance (i.e., glyphosate tolerant and resistant biotypes), will respond to variations in soil moisture, either alone or in combination with other climatic conditions, such as temperature. Further studies involving different weed biotypes under varying temperatures and soil moisture regimes will help in the confirmation of this hypothesis. Better understanding of the interaction seen between climatic variables and a species' natural tolerance would help to develop a set of guidelines for land managers in the application of glyphosate to manage weeds in the NGR.

Author Contributions: Conceptualization, A.M.P. and S.A.; methodology, A.M.P. and S.A.; software, formal analysis, A.M.P.; investigation, A.M.P.; writing—original draft preparation, A.M.P.; writingreview and editing, A.M.P., A.W., C.O. and S.A.; supervision, A.W., C.O. and S.A. All authors have read and agreed to the published version of the manuscript.

Funding: This research received no specific grant from any funding agency in the public, commercial, or not-for-profit sectors.

Acknowledgments: This study is part of the project of Arslan Masood Peerzada who is thankful to the Commonwealth of Australia for the provision of Research Training Program (RTP) Scholarship.

Conflicts of Interest: The authors declare no conflict of interest.

\section{References}

1. Widderick, M.; Cook, T.; McLean, A.; Churchett, J.; Keenan, M.; Miller, B.; Davidson, B. Improved management of key northern region weeds: Diverse problems, diverse solutions. In Proceedings of the 19th Australasian Weeds Conference, Hobart, TAS, Australia, 1-4 September 2014; pp. 206-209.

2. Fromm, G.; Grieger, V. The effect of summer weed management on subsequent grain yield and quality. In Proceedings of the 13th Australian Weeds Conference, Perth, WA, Australia, 8-13 September 2002; pp. 8-13.

3. Hunt, J.; Browne, C.; McBeath, T.; Verburg, K.; Craig, S.; Whitbread, A. Summer fallow weed control and residue management impacts on winter crop yield though soil water and $\mathrm{N}$ accumulation in a winter-dominant, low rainfall region of southern Australia. Crop Pasture Sci. 2013, 64, 922-934. [CrossRef]

4. Cameron, J.; Storrie, A. Summer Fallow Weed Management; Grains Research \& Development Corporation: Canberra, Australia, 2014.

5. Soares, C.; Pereira, R.; Spormann, S.; Fidalgo, F. Is soil contamination by a glyphosate commercial formulation truly harmless to non-target plants?-Evaluation of oxidative damage and antioxidant responses in tomato. Environ. Pollut. 2019, 247, 256-265. [CrossRef]

6. De Moraes, C.P.; de Brito, I.P.; Tropaldi, L.; Carbonari, C.A.; Velini, E.D. Hormetic effect of glyphosate on Urochloa decumbens plants. J. Environ. Sci. Health Part B 2020, 55, 376-381. [CrossRef] [PubMed]

7. Duke, S.O.; Powles, S.B. Glyphosate: A once-in-a-century herbicide. Pest Manag. Sci. 2008, 64, 319-325. [CrossRef] [PubMed] 
8. Tanpipat, S.; Adkins, S.W.; Swarbrick, J.T.; Boersma, M. Influence of selected environmental factors on glyphosate efficacy when applied to awnless barnyard grass (Echinochloa colona (L.)). Aust. J. Agric. Res. 1997, 48, 695-702. [CrossRef]

9. Walker, S.; Widderick, M.; Storrie, A.; Osten, V. Preventing glyphosate resistance in weeds of the northern grain region. In Proceedings of the 14th Australian weeds conference: Weed Management: Balancing People, Planet, Profit, Wagga Wagga, NSW, Australia, 6-9 September 2004; pp. 428-431.

10. Jalaludin, A.; Widderick, M.J.; Broster, J.; Walsh, M.J. Glyphosate and 2, 4-D amine resistance in common sowthistle (Sonchus oleraceus) and fleabane (Conyza bonariensis) in the northern grain growing region of Australia. In Proceedings of the 21st Australasian Weeds Conference 2018: Weed Biosecurity-Protecting our future, Sydney, NSW, Australia, 9-13 September 2018; p. 139.

11. Adkins, S.W.; Tanpipat, S.; Swarbrick, J.; Boersma, M. Influence of environmental factors on glyphosate efficacy when applied to Avena fatua or Urochloa panicoides. Weed Res. 1998, 38, 129-138. [CrossRef]

12. Adkins, S.; Tanpipat, S.; Swarbrick, J.; Boersma, M. The influence of soil moisture content on glyphosate efficacy for the control of annual grasses in fallow land. Weed Res. 1998, 38, 119-127. [CrossRef]

13. Varanasi, A.; Prasad, P.V.; Jugulam, M. Impact of climate change factors on weeds and herbicide efficacy. Adv. Agron. 2016, 135, 107-146.

14. Chaves, M.M.; Maroco, J.P.; Pereira, J.S. Understanding plant responses to drought-From genes to the whole plant. Funct. Plant Biol. 2003, 30, 239-264. [CrossRef] [PubMed]

15. Chaves, M.M.; Pereira, J.S.; Maroco, J.; Rodrigues, M.L.; Ricardo, C.P.P.; Osório, M.L.; Carvalho, I.; Faria, T.; Pinheiro, C. How plants cope with water stress in the field? Photosynthesis and growth. Ann. Bot. 2002, 89, 907-916. [CrossRef]

16. Jaleel, C.A.; Manivannan, P.; Wahid, A.; Farooq, M.; Al-Juburi, H.J.; Somasundaram, R.; Panneerselvam, R. Drought stress in plants: A review on morphological characteristics and pigments composition. Int. J. Agric. Biol. 2009, 11, $100-105$.

17. Foreman, M.H.; Field, R.J. Drought induced tolerance to diclofop-methyl in cultivated oat. In Proceedings of the New Zealand Weed and Pest Control Conference, Palmerston North, New Zealand, 12-14 August 1986; pp. 267-271.

18. Meeusen, R.; Lorey, S.; Yih, R. Effects of environmental factors on the herbicidal activity of acifluorfen. Asp. Appl. Biol. 1983, 4, 253-263.

19. Ahmadi, M.; Haderlie, L.; Wicks, G. Effect of growth stage and water stress on barnyardgrass (Echinochloa crus-galli) control and on glyphosate absorption and translocation. Weed Sci. 1980, 28, 277-282. [CrossRef]

20. Chase, R.L.; Appleby, A.P. Effects of humidity and moisture stress on glyphosate control of Cyperus rotundus L. Weed Res. 1979, 19, 241-246. [CrossRef]

21. McWhorter, C.; Jordan, T.; Wills, G. Translocation of ${ }^{14} \mathrm{C}$-glyphosate in soybeans (Glycine max) and johnsongrass (Sorghum halepense). Weed Sci. 1980, 28, 113-118. [CrossRef]

22. Moosavi-Nia, H.; Dore, J. Factors affecting glyphosate activity in Imperata cylindrica (L) Beauv. and Cyperus rotundas L. Effect of soil moisture. Weed Res. 1979, 19, 137-143. [CrossRef]

23. Waldecker, M.A.; Wyse, D.L. Soil moisture effects on glyphosate absorption and translocation in common milkweed (Asclepias syriaca). Weed Sci. 1985, 33, 299-305. [CrossRef]

24. Quiggin, J. Drought, climate change and food prices in Australia; The University of Queensland: St Lucia, QLD, Australia, 2007.

25. Bajwa, A.A.; Chauhan, B.S.; Adkins, S. Morphological, physiological and biochemical responses of two Australian biotypes of Parthenium hysterophorus to different soil moisture regimes. Environ. Sci. Pollut. Res. 2017, 24, 16186-16194. [CrossRef]

26. Moretti, M.L. Determination of Multiple Herbicide Resistance in Populations of Hairy Fleabane (Conyza bonariensis) in the Central Valley of California and Evaluation of Alternative Chemical Control. Master's Thesis, California State University, Fresno, CA, USA, 2011.

27. Bagavathiannan, M.; Singh, V.; Govindasamy, P.; Abugho, S.B.; Liu, R. Impact of concurrent weed or herbicide stress with other biotic and abiotic stressors on crop production. In Plant Tolerance to Individual and Concurrent Stresses; Springer: New York, NY, USA, 2017; pp. 33-45.

28. Irmak, S.; Haman, D.Z.; Irmak, A.; Jones, J.W.; Campbell, K.L.; Crisman, T.L. Measurement and analyses of growth and stress parameters of Viburnum odoratissimum (Ker-gawl) grown in a multi-pot box system. HortScience 2004, 39, 1445-1455. [CrossRef]

29. Michalk, D.; Herbert, P. The effects of grazing and season on the stability of Chloris Spp. (Windmill grasses) in natural pasture at Trangie, New South Wales. Rangel. J. 1976, 1, 106-111. [CrossRef]

30. Neckář, K.; Brant, V.; Nečasová, M.; Novakova, K.; Venclova, V. Germination of weed species from Asteraceae family under water deficit conditions. J. Plant Dis. Prot. 2008, 125, 271-276.

31. Spencer, D.F.; Tan, W.; Liow, P.-S.; Ksander, G.G.; Whitehand, L.C.; Weaver, S.; Olson, J.; Newhouser, M. Evaluation of glyphosate for managing giant reed (Arundo donax). Invasive Plant Sci. Manag. 2008, 1, 248-254. [CrossRef]

32. Tanpipat, S. Environmental Control of Glyphosate Efficacy: Fallow Weeds of the Australian North-East Grain Belt. Ph.D. Thesis, The University of Queensland, Gatton, QLD, Australia, 1995.

33. Aves, C.S. Herbicide resistance in Conyza bonariensis (L.) Cronquist (flaxleaf fleabane) populations from northeast Victoria and its management in mixed farming systems. Ph.D. Thesis, The University of Adelaide, Adelaide, SA, Australia, 2018.

34. Brito, I.P.; Tropaldi, L.; Carbonari, C.A.; Velini, E.D. Hormetic effects of glyphosate on plants. Pest Manag. Sci. 2018, 74, 1064-1070. [CrossRef] [PubMed] 
35. Ziska, L.H. The role of climate change and increasing atmospheric carbon dioxide on weed management: Herbicide efficacy. Agric. Ecosyst. Environ. 2016, 231, 304-309. [CrossRef]

36. De Ruiter, H.; Meinen, E. Influence of water stress and surfactant on the efficacy, absorption, and translocation of glyphosate. Weed Sci. 1998, 46, 289-296. [CrossRef]

37. Baucom, R.S. Evolutionary and ecological insights from herbicide-resistant weeds: What have we learned about plant adaptation, and what is left to uncover? New Phytol. 2019, 223, 68-82. [CrossRef] [PubMed]

38. Qaderi, M.M.; Kurepin, L.V.; Reid, D.M. Effects of temperature and watering regime on growth, gas exchange and abscisic acid content of canola (Brassica napus) seedlings. Environ. Exp. Bot. 2012, 75, 107-113. [CrossRef]

39. Qaderi, M.M.; Kurepin, L.V.; Reid, D.M. Growth and physiological responses of canola (Brassica napus) to three components of global climate change: Temperature, carbon dioxide and drought. Physiol. Plant. 2006, 128, 710-721. [CrossRef]

40. Larcher, W. Physiological Plant Ecology: Ecophysiology and Stress Physiology of Functional Groups, 4th ed.; Springer-Verlag: Berlin, Germany, 2003.

41. Ohashi, Y.; Nakayama, N.; Saneoka, H.; Fujita, K. Effects of drought stress on photosynthetic gas exchange, chlorophyll fluorescence and stem diameter of soybean plants. Biol. Plant. 2006, 50, 138-141. [CrossRef]

42. Qaderi, M.M.; Lynch, A.L.; Godin, V.J.; Reid, D.M. Single and interactive effects of temperature, carbon dioxide, and watering regime on the invasive weed black knapweed (Centaurea nigra). Ecoscience 2013, 20, 328-338. [CrossRef]

43. Karkanis, A.; Bilalis, D.; Efthimiadou, A. Architectural plasticity, photosynthesis and growth responses of velvetleaf (Abutilon theophrasti Medicus) plants to water stress in a semi-arid environment. Aust. J. Crop Sci. 2011, 5, 369-374.

44. Lovelli, S.; Perniola, M.; Ferrara, A.; Amato, M.; Di Tommaso, T. Photosynthetic response to water stress of pigweed (Amaranthus retroflexus) in a Southern-Mediterranean area. Weed Sci. 2010, 58, 126-131. [CrossRef]

45. Wu, L.-M.; Fang, Y.; Yang, H.-N.; Bai, L.-Y. Effects of drought-stress on seed germination and growth physiology of quincloracresistant Echinochloa crusgalli. PLoS ONE 2019, 14, e214480. [CrossRef] [PubMed]

46. Weller, S.; Florentine, S.; Mutti, N.; Jha, P.; Chauhan, B.S. Response of Chloris truncata to moisture stress, elevated carbon dioxide and herbicide application. Sci. Rep. 2019, 9, 1-10. [CrossRef]

47. Boutraa, T.; Akhkha, A.; Al-Shoaibi, A.A.; Alhejeli, A.M. Effect of water stress on growth and water use efficiency (WUE) of some wheat cultivars (Triticum durum) grown in Saudi Arabia. J. Taibah Univ. Sci. 2010, 3, 39-48. [CrossRef]

48. Sellers, B.A.; Smeda, R.J.; Johnson, W.G. Diurnal fluctuations and leaf angle reduce glufosinate efficacy. Weed Technol. 2003, 17, 302-306. [CrossRef]

49. Da Silva Santos, R.T.; Della Vechia, J.F.; Dos Santos, C.A.M.; Almeida, D.P.; da Costa Ferreira, M. Relationship of contact angle of spray solution on leaf surfaces with weed control. Sci. Rep. 2021, 11, 1-10. [CrossRef]

50. Oosterhuis, D.; Hampton, R.; Wullschleger, S. Water deficit effects on the cotton leaf cuticle and the efficiency of defoliants. J. Prod. Agric. 1991, 4, 260-265. [CrossRef]

51. Rocha-Pereira, M.R.; Klar, A.E.; Martins, D.; Ferreira de Souza, G.S.; Villalba, J. Effect of water stress on herbicide efficiency applied to Urochloa decumbens. Cienc. Investig. Agrar. 2012, 39, 211-220. [CrossRef]

52. Polle, A. Protection from oxidative stress in trees as affected by elevated CO2 and environmental stress. In Carbon Dioxide and Terrestrial Ecosystems; Koch, G., Mooney, H., Eds.; Academic Press: New York, NY, USA, 1996; pp. $299-315$.

53. Ziska, L.H.; Teasdale, J.R. Sustained growth and increased tolerance to glyphosate observed in a C3 perennial weed, quackgrass (Elytrigia repens), grown at elevated carbon dioxide. Funct. Plant Biol. 2000, 27, 159-166. [CrossRef]

54. Bollig, J.; Seiler, J.; Zedaker, S.; Thompson, J.; Lucero, D. Effect of plant moisture stress and application surface on uptake and translocation of triclopyr with organosilicone surfactant in red maple seedlings. Can. J. For. Res. 1995, 25, 425-429. [CrossRef]

55. Ohashi, Y.; Saneoka, H.; Fujita, K. Effect of water stress on growth, photosynthesis, and photoassimilate translocation in soybean and tropical pasture legume siratro. Soil Sci. Plant Nutr. 2000, 46, 417-425.

56. Yanniccari, M.; Istilart, C.; Gimenez, D.O.; Castro, A.M. Glyphosate resistance in perennial ryegrass (Lolium perenne L.) from Argentina. Crop Prot. 2012, 32, 12-16. [CrossRef]

57. Okada, M.; Hanson, B.D.; Hembree, K.J.; Peng, Y.; Shrestha, A.; Stewart Jr, C.N.; Wright, S.D.; Jasieniuk, M. Evolution and spread of glyphosate resistance in Conyza canadensis in California. Evol. Appl. 2013, 6, 761-777. [CrossRef]

58. Darwish, M.; Vidal, V.; Lopez-Lauri, F.; Alnaser, O.; Junglee, S.; El Maataoui, M.; Sallanon, H. Tolerance to clomazone herbicide is linked to the state of LHC, PQ-pool and ROS detoxification in tobacco (Nicotiana tabacum L.). J. Plant Physiol. 2015, 175, 122-130. [CrossRef] [PubMed]

59. Gardner, W. Water retention: Field methods. In Methods of Soil Analysis. Part 1: Physical and Mineralogical Methods; Klute, A., Ed.; Southern Weed Science Society: Westminster, CO, USA, 1986; pp. $29-46$.

60. Peerzada, A.M. Glyphosate Efficacy under Projected Climate Change: Impact on Three Summer Fallow Weeds of Australian Northern Grain Region. Ph.D. Thesis, The University of Queensland, Brisbane, Australia, 2020.

61. Frans, R. (Ed.) Experimental Design and Techniques for Measuring and Analyzing Plant Responses to Weed Control Practices; American Society of Agronomy, Inc.; Soil Science Society of America, Inc.: Madison, WI, USA, 1986; Volume 5.1, pp. $29-46$. 